\title{
Agrostological Interventions and Their Utilization Prospects for Soil and Water Conservation in Hill Agriculture - A Review
}

\author{
Vikas Gupta*, Anil Kumar, Meenakshi Gupta, B. C. Sharma, Mahender Singh, \\ Monica Banotra, Sapna Bhagat and Ashu Sharma
}

Division of Agronomy, FOA, Main Campus, Chatha, SKUAST-Jammu-180009, India

*Corresponding author

\begin{tabular}{|c|c|}
\hline & A B S T RA C T \\
\hline & \multirow{5}{*}{$\begin{array}{l}\text { The paper summarizes research results of the use of different types of } \\
\text { grasses; their use as important and effective vegetative hedge that when } \\
\text { grown on the contour significantly reduces the flow of sediment from } \\
\text { eroding sites and reduces runoff, both simultaneously, and at a low cost, } \\
\text { compared to more traditional engineered practices. Various grasses have } \\
\text { unique characteristics and capability to reduce run off, bind soil at slope } \\
\text { over a wide range of site conditions. These grasses require minimum } \\
\text { maintenance and mostly are resistant to pests and diseases. These are also } \\
\text { used as earth embankments, drainage lines, roads etc. The various soil and } \\
\text { water conservation practices are improved through the use of various } \\
\text { Agrostological measures especially in hill agriculture. }\end{array}$} \\
\hline & \\
\hline $\begin{array}{l}\text { Water conservation, } \\
\text { Hill agriculture, } \\
\text { Interventions }\end{array}$ & \\
\hline Article Info & \\
\hline $\begin{array}{l}\text { Accepted: } \\
\text { 26 October } 2017 \\
\text { Available Online: } \\
10 \text { January } 2018\end{array}$ & \\
\hline
\end{tabular}

\section{Introduction}

For healthy existence of life on earth natural resources like soil and water are the most essential and its management is very essential. Soil provides base for all the activities for growing food, fuel, fodder and shelter but there is continuous depletion of soil and its quality is deteriorating day by day. Due to various factors like shifting cultivation, high rainfall, large scale deforestation, overgrazing etc soil is being eroded. Soil erosion leads to degradation of soils' physical property and loss of plant nutrients. Nature takes about $600-1000$ years to build $2.5 \mathrm{~cm}$ of top fertile soil but it is lost even in a year because of poor management practices. Conservation of soil and water is essential for sustainable production, environment preservation and balanced ecosystem (Samra et al., 2000). Soil degradation has raised an important issue in this modern era. It is the net result of dynamic soil degradative and restorative processes regulated by natural and anthropogenic factors. The degree of soil degradation depends upon soil's susceptibility to degradative process, land use, the duration of degradative land use and the management (Saha et al., 2012). Among the major 
challenges facing the world today is land degradation, unsustainable farming practices, loss of biodiversity, increased risks of climate change and rising hunger, poverty and malnutrition (Oke and Jamala, 2017). The mild slopy land can be changed to terraces in time by adopting the contour bunds with grass retention on contour lines and growing of crops to change the soil erosion.

\section{Stevia}

Medicinal crop stevia gave maximum fresh leaf $(9.13 \mathrm{t} / \mathrm{ha})$, dry leaf $(2.90 \mathrm{t} / \mathrm{ha})$, biomass (35.0 t/ha) yields and stevioside content (7.06 $\%)$ with drip irrigation at $100 \% \mathrm{PE}$ and application of $100 \%$ RD of fertilizers. The application of irrigation and fertilizer through drip has been found to increase nutrient contents both in soil and plants over the surface irrigation, suggesting a balanced fertilization is required for deriving optimum growth, yield and nutrition of the stevia plant (Behera et al., 2013).

\section{Vetiver}

The Vetiver System (VS) is a new phytotechnology based on the use of vetiver grass (Vetiveria zizaniodes L.) for numerous environmental protection applications. VS has been developed from research, development and application programs around the world in the last 15 years. VS is now being used in over 40 countries with tropical and subtropical climates for various environmental protection purposes. This Technical Bulletin reports one of such applications (Truong and Hart, 2001).

Significant mean oil yields to the tune of 13.85 and $14.42 \mathrm{~kg} / \mathrm{ha}$ was noticed when intercropping of pigeon pea and black gram was done in Vetiver grass. Intercropping in vetiver also gave higher monetary returns ad B: C ratio (Maheswari and Sharma, 2003).
Vetiver grass was first recognised in 1995 for having "super absorbent" characteristics suitable for the disposal of leachate and effluent generated from landfill and wastewater treatment plants in Queensland, Australia. Chinese scientists later confirmed these results in 1997 and since then the Vetiver System has been used successfully for these purposes in Australia, China and Thailand (Truong, 2000).

Different cultivars of Vetiver (Vetiveria zizaniodes L.) showed survival (93-98 \%) and remained unaffected by saline irrigation. However, different sources of irrigation water like canal water, saline water and alternate canal and saline water significantly affected shoot biomass whereas root biomass was not affected significantly ((Tomar and Minhas, 2004).

Contour ridges with Vetiver (khus) recorded higher yield of finger millet to the tune of 17.2 q/ha (Patil et al., 2002). Arora and Gupta (2001) reported that V-ditches of $8 \mathrm{~m}$ apart across the slope with continuous row of Vetiver has given highest yield of Chenchrus ciliaris.

Oku and Babalona (2009) studied effect of Vetiver, organamineral fertilizer and bare (control) on down slope primary particle size fractions and physical parameter in erosion prone areas of S-W Nigeria and implied that transportability of eroded sediments on organ mineral fertilizer and bare (control) plots were low down the slope. This is because sand particles are easy to detach but difficult to transport because of the particle size and mass. The predominant texture along the slope under vetiver intervention plot was medium. This implied some clay particles must have been contained in the soils trapped by vetiver hedgerows. Clay particles tend to stick together and are difficult to detach but are carried to great distance once separated 
from the soil mass. The results are also supported by Troeh et al., 1991. Further, vetiver grass intervention imposed favourable permeability on the soils along the slope. Water erosion induces excessive soil permeability on the soils without vetiver hedgerows. Good soil permeability is desirable for optimum fertilizer use by plants and water economy within the plant-resting zone. Excessive permeability leaches plant nutrients down beyond the plant rooting zone.

Vetiver System is a very efficient and low cost method for treating effluent and leachate from both domestic and industrial sources. In domestic situations worldwide, the potential of vetiver grass systems is enormous as a simple, hygienic and low cost means of treating human sewage. Site-specific designs are being refined for vetiver grass planting expanse and medium, for wastewater system flows through the vetiver, and for monitoring total system effectiveness (Truong and Hart, 2001).

\section{Forage production using Sloping Agricultural Land Technology (SALT)}

The technique of using tree legumes to improve the fertility and stability of agricultural soils can be immense use in hilly areas. A conservation farming scheme called Sloping Agricultural Land Technology (SALT), based on the use of tree and shrub legumes finds good use in hilly landscapes. SALT is a simple, applicable, low-cost method of upland farming. It is meant for small farmers with few tools, little capital and knowledge of modern agriculture. SALT is a form of alley farming in which field and perennial crops are grown in bands 4-5 m wide between contour rows of leguminous trees and/or shrubs. The latter are thickly planted in double rows to form hedgerows. Various benefits of SALT include soil protection and amelioration, landscape stability, sustained production and increased economic returns. The species used as hedgerows include Leucaena leucocephala, $L$. diversifolia, Calliandra calothyrsus, Gliricidia sepium and Desmodium rensonii. Farmers are encouraged to use a suitable combination of these species (Gupta et al., 2007).

\section{Carbon storage in silvi-pastoral system}

Grasslands may accrete organic matter in the soil but their contribution is often under emphasized, whereas, the silvi-pastoral system accumulates organic carbon in soil as well as in above ground woody components (Gupta et al., 2007). The silvi-pastoral systems accrete more carbon than pure forest and pastures. Silvi-pastoral systems improve physico-chemical properties. Double soil organic content has been reported in the system than the open situation (Hazra, 1989).

\section{Run off and soil losses}

Adoption of silvipastoral systems in the hills ensures adequate soil cover thereby minimizing the hazards of runoff and soil losses. Runoff and soil losses are substantially reduced when small watershed with agriculture are replaced by trees or grasses or with mechanical measures (Singh et al., 1990). Studies had shown that protected silvipasture cover is best in erosion control than agricultural crops (Chinnamani, 1992). Resorting to silvi-pastoral technique with soil and water conservation measures in Gharawa watershed not only increased forage production, but helped in reducing soil loss from 41.0 to $9.5 \mathrm{t} / \mathrm{ha}$ from barren hillock and 20.5 to 5.5 t/ha from waste lands (Hazra and Singh, 1994 and Hazra, 1993).

The association of commercial grass species, viz., Eulaliopsis binata (Bhabbar), Vetiver zizanioides and Saccharum munja, with 
Acacia nilotica significantly reduced runoff and soil erosion over its pure plantation throughout the growing period. Allowing natural grasses to grow under Acacia nilotica also caused the reductions, but these were less than for commercial grass-based systems. The association of the grasses under different silvipastoral systems affected growth of the trees to varying degrees, resulting in the reduction of biomass yields and ultimately economic returns. Acacia nilotica with Vetiver zizanioides proved the most compatible system and is recommended for sustainable biomass production, checking land degradation and higher economic returns from degraded land of the Lower Himalayas (Yadav et al., 2014).

\section{Vegetative barrier/water use}

Chand and Bhan (2002) studied growth, root development, water use and WUE of different sorghum varieties grown in the alleys of various vegetative barriers viz. Sesbania sesban, Leucaena leucocephala, Cajanus cajan, Vetiveria zizaniodes, Cenchrus ciliaris and unbarriered (control) and concluded that sorghum (var. Varsha) could be grown in 5.4 $\mathrm{m}$ wide alleys of Sesbania sesban or Leucaena leucocephala planted in paired rows at $0.5 \mathrm{~m}$ apart and pruning them at a height of $60 \mathrm{~cm}$ at the time of sowing of sorghum crop. And at 45 DAS, using the biomass as mulch between the crop rows for obtaining higher root development, water use efficiency, grain and stover yields over sorghum crop grown under unbarriered plots. By adoption of this technique, problems like moisture scarcity and poor fertility in slopy and light textured of dryland areas of Uttar Pradesh (UP) could be solved to some extent.

Panicum maximum (Guinea grass), Vetiveria zizanioides (Khuskhus) and Eulaliop sisbinata (Bhabar) have been found suitable for vegetation strips in the Shivalik hills (Lal et al., 1996). These three species are used as barriers for effective erosion and sediment control because they form an erect, stiff and uniformly dense hedge so as to offer high resistance to overland water flow. These vegetation strips result in minimal loss of crop yield, the species do not proliferate as weeds, they do not compete for moisture, nutrients and light, they are not hosts for pest and diseases, and they often provide some additional economic benefits to farmers (Bhardwasj, 1994). For example, Palmarosa (Cymbopogon martini) is a grass species that yields oil of high economic value (0.04$0.05 \%$ oil), with potential for reducing slope erosion and capturing sediment (Ghosh et al., 2015).

\section{Soil and moisture conservation}

Vetiver Grass Technology (VGT) as compared to stone barriers, lemon grass, and bare ground (control) under natural (total rainfall $689 \mathrm{~mm}$ ) and artificial rainfall conditions proved to be the most effective technology for reducing soil and water losses. VGT reduced rainfall run off and soil loss by about 57 and 80 per cent, respectively (Rao et al., 1991). Vetiver showed a distinct improvement in efficiency as the hedges become older and more dense (Rao et al., 1992). At CIAT, Colombia, Vetiver was compared to other vegetative systems grown in conjunction with cassava. At 11 months (rainfall $1240 \mathrm{~mm}$ ) vetiver hedges reduced soil loss from 142 t/ha (bare fallow) to 1.3 t/ha for cropped cassava between vetiver hedges. Also, rainfall run off was reduced from 11.6 to 3.6 per cent (Laing and Ruppenthal, 1991).

\section{Conservation (Grasses)}

Verma et al., 2010 evaluated five different grass species to assess their suitability as biological reclaiming agent and vegetative 
barriers for reclaiming as well as reducing soil erosion and enhancing in situ water conservation in a moderate sodic clay soil.
The results revealed that lowest soil loss and runoff were observed in the plots planted with Marvel grass (Dichanthium annulatum).

Table.1 Various parameters as observed through different measures

\begin{tabular}{|c|c|c|c|c|c|}
\hline Treatments & Runoff (mm) & $\begin{array}{l}\text { Soil loss } \\
\text { (t/ha/year) }\end{array}$ & $\begin{array}{l}\text { Ragi yield } \\
\text { (q/ha) }\end{array}$ & $\begin{array}{l}\text { Runoff control } \\
\text { efficiency }(\%)\end{array}$ & $\begin{array}{l}\text { Soil loss control } \\
\text { efficiency }\end{array}$ \\
\hline Control $\left(T_{1}\right)$ & 206.20 & 8.63 & 8.26 & - & - \\
\hline $\begin{array}{l}\text { Geranium grass } \\
\left(T_{2}\right)\end{array}$ & 121.58 & 3.54 & 7.90 & 46.50 & 62.94 \\
\hline $\begin{array}{l}\text { Lemon grass } \\
\left(T_{3}\right)\end{array}$ & 91.80 & 2.69 & 10.40 & 56.48 & 70.34 \\
\hline $\begin{array}{l}\text { Citronella grass } \\
\left(T_{4}\right)\end{array}$ & 102.65 & 3.75 & 9.43 & 49.96 & 58.96 \\
\hline $\begin{array}{l}\text { Contour bund } \\
\left(\mathrm{T}_{5}\right)\end{array}$ & 85.80 & 1.74 & 8.20 & 53.46 & 80.78 \\
\hline $\begin{array}{l}\text { Graded bund } \\
\left(T_{6}\right)\end{array}$ & 73.89 & 4.44 & 8.96 & 65.26 & 50.72 \\
\hline $\begin{array}{l}\text { Graded bund + } \\
\text { Vetiver }\left(\mathrm{T}_{7}\right)\end{array}$ & 71.26 & 1.56 & 8.70 & 65.63 & 83.03 \\
\hline
\end{tabular}

The order of performance for adoption of different grass species with regards to fodder and commercial value for sodic Vertisols was Marvel grass (Dichanthium annulatum), Para grass (Brachiria mutia), Napier (Pennisetum perpurium), Karnal (Diplachne fusca) and Vetiver (Vetiveria zizinoides). Planting of these grasses in sodic clay soils protect natural resources (sediment and nutrient losses) and are helpful in reclaiming these soils.

The grasses on their decay, add carbohydrates (simple sugars, starch, cellulose), protein and fats to the soils which promotes soil aggregation. This also results in reducing soil erosion and run-off losses. Grass roots, penetrating into the soils have been observed in two years old grasses like Cenchrus ciliaris, C. serigerus, Lasiurus sindicus and Pandicum anidotale on sandy soil in Kangra area of Himachal Pradesh. The roots of these grasses penetrated to $150,125,320$ and 210 $\mathrm{cm}$, respectively and produced lot of root matter (Gupta and Arora, 2010). Besides providing fodder, the grasses protect soil conservation structures like terrace bunds and waterways. Encouraging results of Bhabbar grass (Eulaliopsis binata) for conserving degraded bouldry lands and stabilization of steep slopes and gullies near Dehradun.

Raising jointly, grass species like Chrysopogon fulvus (at $0.75 \times 0.75 \mathrm{~m}$ ) and species like Dalbergia sisso (at $9.14 \times 9.14$ $\mathrm{m}$ ) in V and VI land capability classes, have shown not only a high yield of air dry grass (10.55 t/ha/year) but also about $64 \mathrm{t}$ fuel wood was available after 19 years. There was also sufficient control of soil and run-off losses (Gupta and Arora, 2010). Narayana (1982) reported that the replacement of annual grasses such as Aristida furiculata and Themeda triandra by Apluda mutica, Heteropogon contortus, Dicanthium annulatum and Cenchrus spp. in ravine lands, has resulted in a natural reduction in run-off and soil loss along with improvement in the 
quality and quantity of grass yields. In a bid to stop soil erosion in erosion in eroded areas and community wastelands of Himachal Pradesh, the farmers have been encouraged to grow shrubs such as Mimosa himalayana, Desmodium spp., Carissa spinarum and Adhatoda vasica for the Siwalik Himalayas and various Quercus species, and coniferous for middle Himalayas (Sharma et al., 1998). These shrubs serve the dual purpose of meeting the villager's firewood need and helping soil and water conservation by preventing run-off. Besides, efforts were made to grow grass species such as Cenchrus and Stylosanthes to supplement the fodder and strengthen the soil (Gupta and Arora, 2010).

\section{Soil fertility}

Dichrostachys cinerea based silvipastoral system significantly improved soil fertility at different row spacings in terms of OC, available nitrogen and phosphorus (Singh et al., 2004).

\section{Grassland}

Rafique and Thakuria (2002) introduced Kazungula grass (Setaria sphacelata) in natural grassland and concluded that introduction of Setaria can be done at a spacing of $40 \mathrm{~cm} \times 40 \mathrm{~cm}$ in natural grassland without killing the existing vegetation and the application of $120 \mathrm{~kg} \mathrm{~N} / \mathrm{ha}$ or even more for higher production of quality herbage.

It was concluded by Xia et al., (2000).

Vetiver can be established and survives in hydroponic conditions.

Vetiver has a high level of tolerance to polluted water.

Vetiver is very effective in removing pollutant from landfill leachates, particularly $\mathrm{N}$ and $\mathrm{P}$.
Vetiver grows rapidly and has a huge biomass. To sustainably remove pollutants from leachates, vetiver shoots should be trimmed 2-3 times per year.

\section{Soil conservation}

Bioengineering measures improved the growth of cashew as compared to control plot. There was significant difference in growth parameters of cashew plants after 12 months of planting among the treatments. Growth performance of cashew was found better under continuous contour trenches with vegetative barriers among the bioengineering measures. The highest cashew nut yield of 7.72 and $14.21 \mathrm{q} / \mathrm{ha}$ was recorded in treatment comprising of continuous contour trenches with Stylosanthes scabra and Vetiveria zizaniodes. The lowest mean cashew nut yield of $3.91 \mathrm{q} / \mathrm{ha}$ was observed in control plot where there was no conservation measure. Continuous contour trenches with Stylosanthes scabra and Vetiveria zizaniodes could be able to increase the cashew yield three times more than conventional methods. Thus, continuous contour trenches with Stylosanthes scabra and Vetiveria zizaniodes as a bioengineering measure is recommended for cashew crop grown in lateritic soils of sloppy land (Manivannan et al., 2009).

\section{Incorporation of jungle grass}

Long-term eff ects of different locally available grasses and weeds on soil hydrophysical properties and rice yield through a 5year field experimentation under hilly ecosystem of Meghalaya depicted that incorporation of jungle grass (Ambrosia spp.), in puddled rice improved soil organic carbon (SOC) by $21.1 \%$, the stability of micro aggregates, moisture retention capacity and infiltration rate of the soil by $82.5,10.0$, and $31.3 \%$, respectively, and soil bulk density decreased by 12.6 per cent. Locally available 
jungle grasses are equally good as an organic amendment, which would also ease the problem of disposal of these grasses during peak monsoon. Therefore, these organic sources may serve as alternative to farm yard manure (FYM) and have a dramatic eff ect on long-term productivity of rice (Saha and Mishra, 2009).

Mane et al., (2009) studied the comparative performance of different soil conservation measures on steep slopes of Konkan region of W. Maharashtra and concluded that different treatments showed a reduction in runoff and soil loss over control. The mechanical structures contour bund $\left(\mathrm{T}_{5}\right)$, graded bund $\left(\mathrm{T}_{6}\right)$ and graded bund + vetiver grass $\left(\mathrm{T}_{7}\right)$ across the land scope were effective in reducing surface runoff and increasing opportunity time, thus helping in conserving water in the micro-watershed areas. The highest average yield of ragi was obtained in treatment $\mathrm{T}_{3}(10.40 \mathrm{q} / \mathrm{ha})$ followed by $\mathrm{T}_{4}, \mathrm{~T}_{6}$, $\mathrm{T}_{7}, \mathrm{~T}_{4}$ and $\mathrm{T}_{1}$. However, the average lowest ragi yield $(7.90 \mathrm{q} / \mathrm{ha})$ was observed in $\mathrm{T}_{2}$ treatment. The maximum runoff control efficiency (\%) and soil loss control efficiency $(\%)$ was achieved by graded bund + vetiver grass $\left(\mathrm{T}_{7}\right)$. Thus, graded bund plus vetiver grass conserved basic resource i.e. soil and water significantly along with minimum losses to the resources. It has also sustained productivity of ragi crop on sloping agricultural lands which is be of immense benefit for the region.

\section{References}

Truong, P. and Hart, B. 2001. Vetiver system for waste water treatment. Pacific Rim Vetiver Network Technical Buletin No. 2001/2 pp: 1-25.

Truong, P.N. 2000. The Global Impact of Vetiver Grass Technology on the Environment. In: Proc. of $2^{\text {nd }}$
International Vetiver Conference, Thailand, January 2000.

Xia, H. P., Liu, S. and AO, H. 2000. Study on Purification and Uptake of Vetiver Grass to Garbage Leachate. In: Proc. of $2^{\text {nd }}$ International Vetiver Conference, Thailand, January 2000.

Samra, 1.S., Sharma, A.R. and Khola, O.P.S. 2000. Sustaining crop production through resource conservation. Indian experience. Proceedings of First International Agronomy Congress on Agronomy. Environment and Food Security for $21^{\text {st }}$ Century (Eds. Panjab Singh, Rajendra Prasad and I.P.S., Ahlawat). Indian Society of Agronomy, New Delhi, India, pp. 117-134.

Mane, M. S., Mahadkarand, U. V. and Thorat, T. N. 2009. Comparative performance of different soil conservation measures on steep slopes of Konkan region of western Maharashtra. Indian Journal of Soil Conservation, 37 (1): 41-44.

Oke, D and Jamala, G. 2017. Traditional agroforestry practices and woody species conservation in the derived savanna ecosystem of Adamawa state, Nigeria. International Journal of Agroforestry and Silviculture, 4 (3): 278-284.

Saha, R., Chaudhary, R. S. and Somasundaram, J. 2012. Soil health management under hill agroecosystem of North East India. Applied and Environmental Soil Science, pp: 1-9 doi: 10.1155/2012/696174.

Chand, M. and Bhan, S. 2002. Root development, water use and water use efficiency of sorghum (Sorghum bicolor) as influenced by vegetative barriers in alley cropping system under rainfed condition. Indian Journal of Agronomy, 47 (3): 333-339.

Rafique, N. T. and Thakuria, K. 2002. Effect of introduction of Kazungula grass (Setaria sphacelata), spacing and 
nitrogen on the productivity of a natural grassland. Indian Journal of Agronomy, 47 (4): 571-575.

Verma, S. K., Raghuvanshi, S. R. S. and Sharma, R. K. 2010. Hydrological behaviour and rooting patterns of some grass species planted in sodic Vertisols under rainfed conditions. Journal of Soil and water Conservation, 9 (3): 159-165.

Keshwa, G. L. and Singh, M. 2004. Biomass production and soil fertility from Dichrostachys cinerea + Cenchrus silvipastoral system in arid and semiarid regions. Indian Journal of Agronomy, 49 (4): 293-295.

Tomar, O. S. and Minhas, P. S. 2004. Relative performance of aromatic grasses under saline irrigation. Indian Journal of Agronomy, 49 (3): 207-208.

Maheswari, S. K. and Sharma, R. K. 2003. Root and oil yield of vetiver (Vetiveria zizaniodes) as influenced by fertilizer management in an intercropping system. Indian Journal of Agronomy, 48 (2): 145-147.

Behera, M. S., Verma, O. P., Mahapatra, P. K., Singandhupe, R. B., Kumar, A., Kannan, K. and Brahmanad, P. S. 2013. Effect of fertigation on stevia (Stevia rebaudiana) under drip irrigation. Indian Journal of Agronomy, 58 (2): 243-250.

Gupta, S. K., Raina, N. S. and Sehgal, S. 2007. Potential of Silvi-Pastoral systems in improving the forage production in the hills of Jammu and Kashmir. Journal of Research, SKUAST-J, 6 (2): 160-168.

Hazra, 1989. Forage and soil productivity under agroforestry and silvipasture systems in Bundelkhand region. In: Promotion of fuel wood trees (Eds. Hedge, N. G., Relwani, L. L. and Kelkar, V. K.) BAIF, Pune pp: 83-88.
Singh, G., Shastri, G. and Bhardwaj, S. P. 1990. Water shed response to conservation measure under different agroclimatic regions in India. Indian Journal of Soil Conservation, 18: 1622.

Chinnamani, S. 1992. Silvi-pasture and natural grassland of Mahi ravines and ravines of Gujarat. Range Management and Agroforestry, 13: 175-189.

Hazra, C. R. and Singh, D. P. and Singh, D. P. 1994. Soil and water conservation and silvi-pastoral for wasteland improvement at Gaharawa watershed. Range Management and Agroforestry, 15: 35-42.

Hazra, C. R. 1993. Tree based rainfed forage production and its influence on soil fertility for Bundelkhand region. Indian Journal of Soil Conservation, 21: 1-7.

Patil, P. P., Gutal, G. B. and Purkar, J. K. 2002. Effect of engineering and vegetative measures on soil erosion and yield of finger millet in Western ghat zone. In: National Symposium on soil and water conservation measures and sustainable land use systems with special reference to the Western ghat region, Invited and contributed papers, ICAR Research Complex for Goa, Goa, India pp: 17-19.

Arora, D. and Gupta, A. K. 2001. Effect of water conservation measures in a pasture on the productivity of Cenchrus ciliaris. In: S. K. Dhyani, S. K. (Eds.), Proceedings of national conference on Resource Conservation and Watershed Management, IASWC, CSWCRTI, Dehradun pp: 52.

Manivannan, S., Rajendran, V. and Thiyagarajan, G. 2009. Effect of bioengineering measures on growth and yield of cashew (Anacardium occidentale) in lateritic soils of Konkan region. Journal of Soil and water Conservation, 8 (2): 14-20. 
Troeh, 1F. R. J., Hobbs, A. and Donnahue, R. L. 1991. Soil and water conservation. $2^{\text {nd }}$ Edition. Prentice Hall. EnglewoodCliffs. New Jersey pp: 81-87.

Oku, E. E. and Babalola, O. 2009. Effects of down slope distance on primary particle size fractions and physical parameters in erosion prone Southwest Nigeria. Journal of Soil and water Conservation, 8 (2): 21-24.

Gupta, R. D. and Arora, S. 2010. Watershed management and Eco-restoration of degraded lands in Northwest Himalayas. Journal of Soil and water Conservation, 9 (4): 249-254.

Sharma, P. D., Sharma, S. P., Sharma, K. D. and Minhas, R. S. 1998. Status report on catchments of Giri and Batq rivers in Himachal Pradesh. Department of Soil Science, HPKVV, Palampur.

Dhruva Narayana V. V. 1982. Souvenir. $12^{\text {th }}$ International Congress Soil Science, Indian Society Soil Science, 8-16 February, 1982, New Delhi.

Saha, R. and Mishra, V. K. 2009. Effect of organic residue management on soil hydro-physical characteristics and rice yield in eastern Himalayan region, India. Journal of Sustainable Agriculture, 33 (2): 161-176.

Lal, R. K., Sharma, J. R. and Mishra, H. O. 1996. Varietal selection for high root biomass and oil yield in Vetiver. Vetiver newsletter no. 15 pp: 18.
Bhardwasj, S. P. 1994. Vegetative barrier as effective economic and eco-friendly measures for erosion control on agricultural lands. In Abstracts of the 8th ISCO Conference, New Delhi pp: 221-228).

Ghosh, B. N., Dogra, P., Sharma, N. K., Bhattacharyya, R. and Mishra, P. K. 2015. Conservation agriculture impact for soil conservation in maize-wheat cropping system in the Indian subHimalayas. International Soil and water Conservation Research, 3: 112118.

Rao, K. P. C., Cogle, A. L. and Srivastava, K. L. 1991. Conservation Effects of Porous and Vegetative Barriers. ICRISAT, Annual Report 1991, Resource Management Program. 1992. ICRISAT, Patancheru, Telangana 502 234, India.

Rao, K. P. C., Cogle, A. L. and Srivastava, K. L. 1992. Conservation Effects of Porous and Vegetative Barriers. ICRISAT, Annual Report 1992, Resource Management Program. 1992. ICRISAT, Patancheru, Telangana 502 234, India.

Laing, D.R. and Ruppenthal, M. 1991. Vetiver News Letter 8, June 1992, Asia Technical Department, The World Bank, Washington DC.

\section{How to cite this article:}

Vikas Gupta, Anil Kumar, Meenakshi Gupta, B.C. Sharma, Mahender Singh, Monica Banotra, Sapna Bhagat and Ashu Sharma. 2018. Agrostological Interventions and Their Utilization Prospects for Soil and Water Conservation in Hill Agriculture - A Review. Int.J.Curr.Microbiol.App.Sci. 7(1): 3514-3522. doi: https://doi.org/10.20546/ijcmas.2018.701.413 